\title{
Molecular identification of phytoplasmas associated with three floricultural species in Hungary
}

\author{
Orsolya Viczián ${ }^{1} \cdot$ József Fodor ${ }^{1} \cdot$ János Ágoston ${ }^{2} \cdot$ Emese Mergenthaler $^{1}$ (D)
}

Received: 11 October 2019 / Accepted: 25 July 2020 / Published online: 31 August 2020

(C) The Author(s) 2020

Keywords 'Candidatus Phytoplasma asteris' · Gaillardia $\cdot$ Echinacea $\cdot$ Aquilegia

Gaillardia aristata, Echinacea purpurea (Asteraceae) and Aquilegia coerulea (Ranunculaceae) are popular perennial garden plants. In 2017 and 2018, over 5\% of G. aristata 'Arizona Apricot', E. purpurea 'Cheyenne Spirit' and A. coerulea 'Biedermeier' plants were affected by stunting, virescence and phyllody in a commercial nursery in Hungary. These symptoms were present in 182 out of 3500 Aquilegia, in 28 out of 520 Echinacea and 470 out of 10080 Gaillardia plantlets, with $5.2 \%, 5.38 \%$ and $4.66 \%$ infection rates, respectively. Leaf samples were collected from fifteen symptomatic and five symptomless plants of each species. Total DNA was extracted by CTAB method and nested PCR assays were performed using primer pair P1/P7 followed by R16F2n/R16R2 (Lee et al. 1998 and references therein). The $1.2 \mathrm{~kb} 16 \mathrm{~S}$ rDNA fragment was amplified from each symptomatic plant separately. Restriction fragment length polymorphism analysis with AluI, HaeIII, HpaII, MseI and $R s a \mathrm{I}$ enzymes yielded restriction profiles identical to each other and to those of reference strain AY1 (GenBank accession number AF322644) belonging to the 16SrI-B subgroup (Lee et al. 1998). The P1/P7-amplified products obtained from G. aristata, E. purpurea and A. coerulea were cloned,

Electronic supplementary material The online version of this article (https://doi.org/10.1007/s42161-020-00624-0) contains supplementary material, which is available to authorized users.

Emese Mergenthaler

mergenthaler.emese@agrar.mta.hu

1 Plant Protection Institute, Centre for Agricultural Research, Herman Ottó str. 15, Budapest 1022, Hungary

2 Department of Horticulture, Faculty of Horticulture and Rural Development, John von Neumann University, Erdei Ferenc Square 1-3, Kecskemét 6000, Hungary sequenced and deposited in GenBank under accession numbers MK992773, MK992774 and MK992775, respectively. BLAST searches of GenBank yielded 99.8-100\% sequence similarities to 'Candidatus Phytoplasma asteris' strain SAY (AF222063).

In subsequent experiments, the elongation factor $\mathrm{Tu}$ (tuf), ribosomal protein ( $r p$ ) operon ( $r p l 22$ and $r p s 3)$ and the molecular chaperonin groEL genes were examined according to Lee et al. (2004) and Mitrović et al. (2011). The PCR products obtained with primer pairs fTufl/rTufl, rpF1/rpR1 and AYgroelF/AYgroelR were cloned and sequenced (MN526022-MN526024). Identical sequences were obtained from the three plant species, sharing 100\% identity with AY phytoplasma strain IRap (AJ271316), Onion proliferation phytoplasma strain OnP2 (GU228514) and AY phytoplasma strain AVUT (AB599686). The three phytoplasma isolates were classified into subgroups tufI-B, rpI-B and groELI-III. To our knowledge this is the first identification of ' $\mathrm{Ca}$. $\mathrm{P}$. asteris' in G. aristata, E. purpurea and A. coerulea in Hungary.

Acknowledgements Open access funding provided by ELKH Centre for Agricultural Research.

Open Access This article is licensed under a Creative Commons Attribution 4.0 International License, which permits use, sharing, adaptation, distribution and reproduction in any medium or format, as long as you give appropriate credit to the original author(s) and the source, provide a link to the Creative Commons licence, and indicate if changes were made. The images or other third party material in this article are included in the article's Creative Commons licence, unless indicated otherwise in a credit line to the material. If material is not included in the article's Creative Commons licence and your intended use is not permitted by statutory regulation or exceeds the permitted use, you will need to obtain permission directly from the copyright holder. To view a copy of this licence, visit http://creativecommons.org/licenses/by/4.0/. 


\section{References}

Lee IM, Gundersen DE, Davis RE, Bartoszyk IM (1998) Revised classification scheme of phytoplasmas based on RFLP analyses of 16S rRNA and ribosomal protein gene sequences. Int J Syst Bacteriol 48: 1153-1169. https://doi.org/10.1099/00207713-48-4-1153

Lee IM, Gundersen-Rindal DE, Davis RE, Bottner KD, Marcone C, Seemüller E (2004) 'Candidatus Phytoplasma asteris', a novel phytoplasma taxon associated with aster yellows and related diseases.
Int J Syst Evol Microbiol 54:1037-1048. https://doi.org/10.1099/ijs. 0.02843-0

Mitrović J, Kakizawa S, Duduk B, Oshima K, Namba S, Bertaccini A (2011) The groEL gene as an additional marker for finer differentiation of 'Candidatus Phytoplasma asteris'-related strains. Ann Appl Biol 159:41-48. https://doi.org/10.1111/j.1744-7348.2011.00472.x

Publisher's note Springer Nature remains neutral with regard to jurisdictional claims in published maps and institutional affiliations. 